\title{
說話
}

\section{觀測の結果を數式にて表はす事及 簡單なる最小自乘法}

藤 原 咲 平

\$1。實驗公式と理論公式

實驗及は觀測の結果快普通表を以て示す。少之を明暸ならしむる第

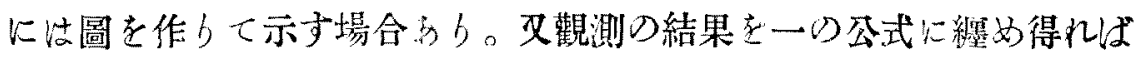
取报て上至極便利なっ。今海簡單なる場合に就さて公式の作り方を説 明す可し。

公式に二種あり、理論公式及實驗会式之なら。例へば地中溫度を表

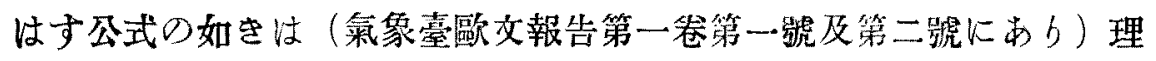
論を根底として作り出されたる8のなる。之に反して氣體の方則（ボ イルシャールの法則) の如穵すの烛實驗上氣體の壓力㳉溫度に比例し て增し體積は之に逆心娍吉る事を知らて、此事實を式にて表はしたる 迄の8の小b。多くの公式の中には理論公式上賽驗公式の合の子の8 のあb。例へば乾濕球濕度計の公式の如きは Maxwell 等の理論によ

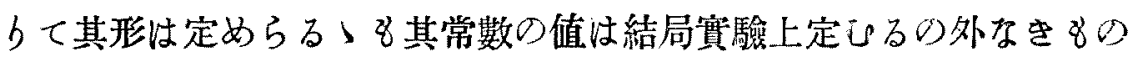
るら此間の關係を一層明暸ならしめんが䉆に熱傳導に關する一例を述 si可し。

平行なる二面の間に挾まれれる厚さdるる板状り物體あb、(例へば 
地殼を平板よりるる8のと考へたる場合の如し）其上下雨面は常に一 定の溫度 $\theta_{0}$ 及 $\theta_{\mathrm{i}}$ を示し、 $\theta_{\mathrm{i}}$ の方高溫々bをす可し、 $\theta_{0}$ の方よb內部に向

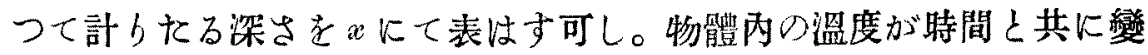
化せざる場合に性體內の溫度配布は次式にて表注さる

$$
\theta=\theta_{n}+\frac{\theta_{i}-\theta_{0}}{d} x
$$

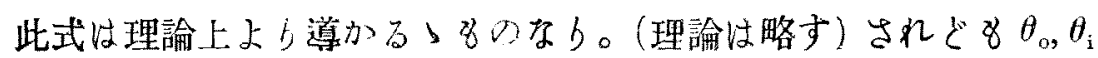

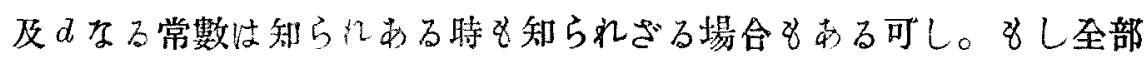

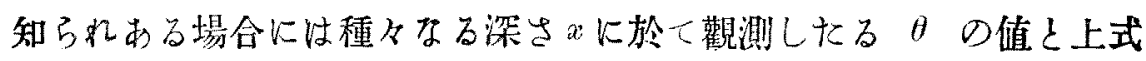
に下計算したる $\theta$ の值とを比較して此否式の適否老驗するを得可 L。

\section{\$2. 平均及確らしき誤差}

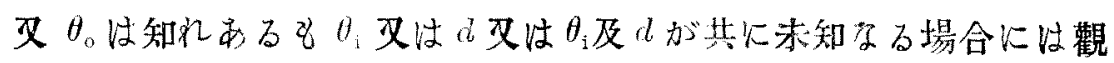

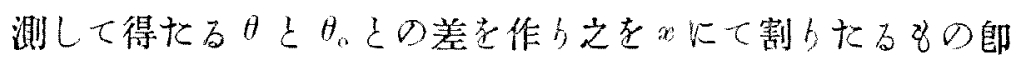

$$
\frac{\theta-\theta_{0}}{a}=\frac{\theta_{1}-\theta_{0}}{d}=\mathrm{G}(\text { と名く })
$$

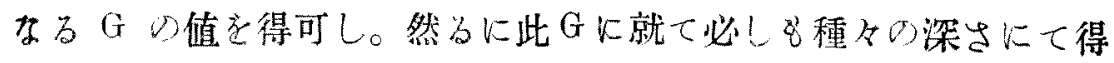

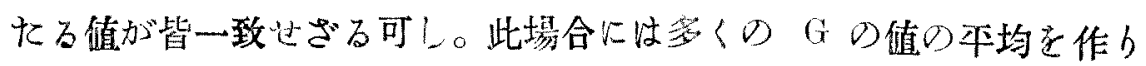
之を $G_{\mathrm{m}}$ とて表はせば個々りGと $\mathrm{G}_{\mathrm{m}}$ との差を作り此等の差が賽驗或

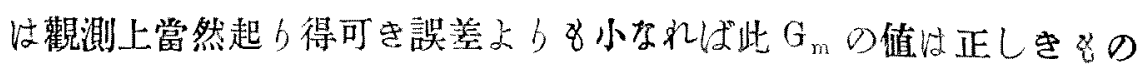

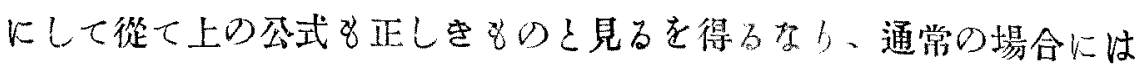
誤差の理論上礁らしき誤差と名：る8の計算して此值を以て誤差の

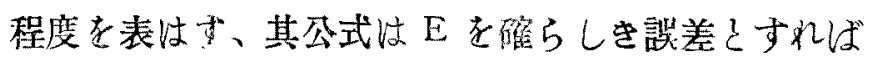




$$
\mathrm{E}=0.6745 \sqrt{\frac{\sum\left(\mathrm{G}-\mathrm{G}_{\mathrm{m}}\right)^{2}}{n(n-1)}}
$$

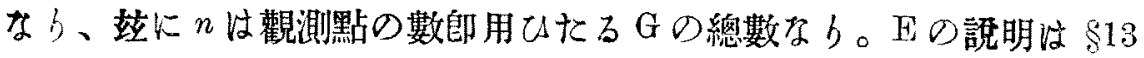
に於て逨分可し。 $n$ は可成大なる數るるを要す。

\section{次式の平均及最小自乘法}

8 ᄂ 8 上の如き場合に於て $\theta_{\mathrm{i}}$ 及 $d$ と共に $\theta_{0} 8$ 亦未知るる場合あbを す可し、此如き場合に8 觀測の數が苦ければ諸常数り值孛決定し且公

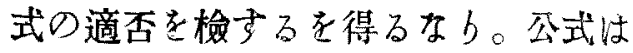

$$
\theta=\theta_{0}+G_{a}
$$

$x_{1} \cdot x_{2}, x_{3} \cdots \cdots \cdots n_{n}$ の諸點に於て觀測したる $\theta$ の值を夫れ夫れ $\theta_{1}, \theta_{2}$, $\theta_{3} \cdots \theta_{n}$ 上す可し、依って此公式が正しき8のとすれば

$$
\begin{aligned}
& \theta_{1}=\theta_{0}+G x_{3} \\
& \theta_{2}=\theta_{0}+G x_{2} \\
& \theta_{3}=\theta_{0}+G x_{3} \\
& \theta_{n}=\theta_{n}+G x_{n}
\end{aligned}
$$

なるn個の一次施式を得可し、此中の何れの二式を用りる8聯立一 次方程式として未知數 $\theta$ 。不 $\mathrm{G}$ を洪定し得可し。然れ共觀測の誤差及 他現象の影䉪等の䉆に異なったる方程式の組よb得たる常數は多少の

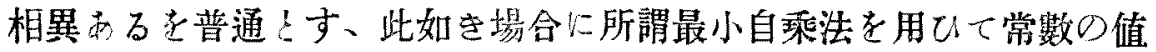

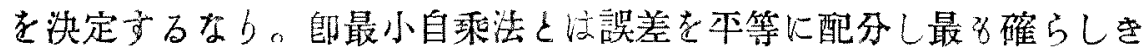
值を求むる算法にして 8 に於て諭じて乃普通の平均法8 亦最小自乘 法の原理に合する8のなb、最小自乘法の説明に入るに先代ちて貫驗 公式の作り方に就さて一言す可し。 


\section{4. 賽驗公式(Empirical Formula)}

觀测及壮實驗の結果はすれ共、格別之に對する理論るさ場合に於て は所謂實驗式妾作る。實驗式を作る順序は先づ實驗の結果を圖に作り 見万可し、圖上より、直線的の變化をなすか或は抛物線型、雙曲線型、 對數曲線型乃至正弦曲線型其他の何几に屬するや見るなら、8し實 驗の結果が此れ等す中の何れかに略近似しあれば、其曲線の方程式を 書さ其式中D常数を前揭牛墔諭公式の時の如くして定さるなら。此方

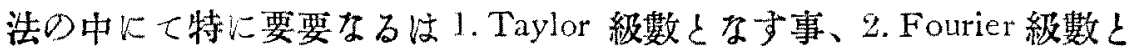

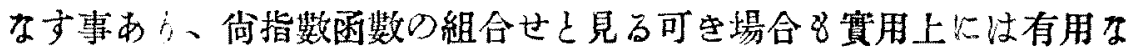

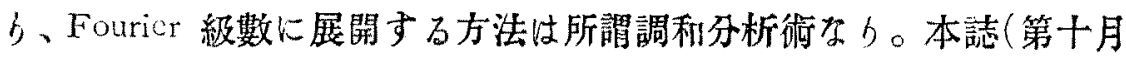

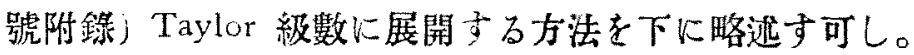

\section{\$0. Taylor 級數}

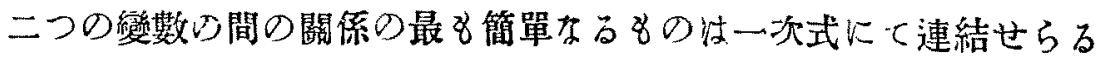

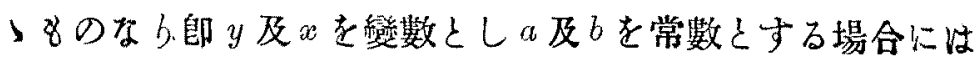

$$
y=a+b x
$$

凡そ如何に椱雜ふる關係ぶニつの變數の間にありとする8變數の極 めて㷋き部分を考ふれば常に其閣係は一次式に歸するなら。之を圖上 より筧明すれば

假りにyといとの關係が圖に示卞曲線の如き8のなる場合には此れを 決して直線的の關係（䬦一次方程式にて表はし得る關係）と考一難し 然れ共任意の一點 $\mathrm{P}$ ○近傍に $x_{1}$ 及 $x_{2}$ る範圍を取って考ふる特には 


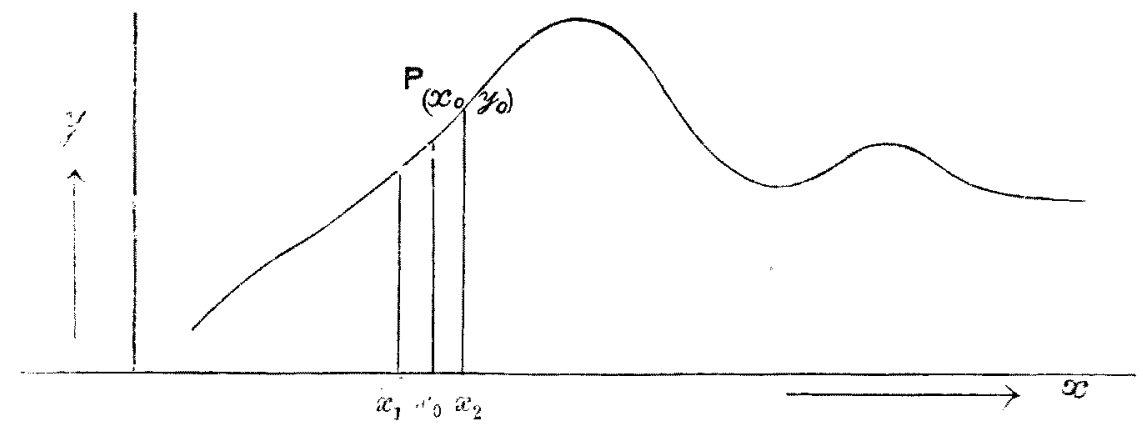

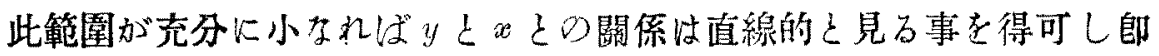
上に示すが如さ一次方程式に大表はし得るなり、或は少しく變形して

$$
y=y_{0}+u\left(x-x_{0}\right)
$$

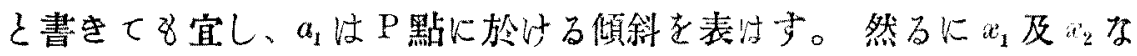

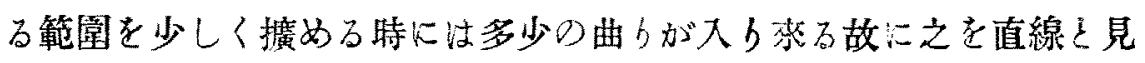

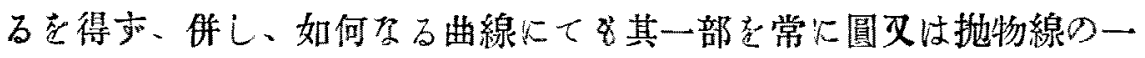

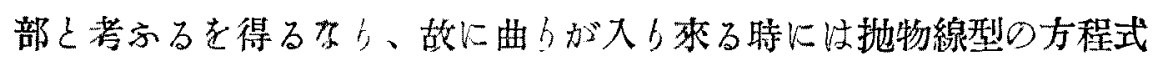
を㨲用して

$$
y=y_{0}+a_{1}\left(x-x_{0}\right)+a_{2}\left(x-x_{0}\right)^{2}
$$

と書く、 $a_{1}$ 及 $a_{2}$ は或常數子b。此式注一方上与見れば前揭の一次式の 右邊に二次の項 $a_{2}\left(x-x_{0}\right)^{2}$ を補足として加へて近似の步を進好をる8 のと8見る老得可し、 $x$ 一。が小なる範圍子る故に $\left(x-x_{0}\right)^{2}$ 沈無論小 みる8のかり。斯の如くして次第に近似り步を進むるに從し高次の項 を附加して 


$$
y=y_{0}+a_{1}\left(x-x_{0}\right)+a_{2}\left(x-x_{0}\right)^{2}+a_{3}\left(x-x_{0}\right)^{3}+\cdots+a_{\mathrm{n}}\left(x-x_{0}\right)^{\mathrm{n}}
$$

と書けば、曲線が如何に椱雑っる場合に8n。適當に大に取りざ すれば充分必要に應して精確に $y$ 袁はし得るなり、實は數學上 Taylorの級數は上の如さ級數の無限迄進みてる8のにして如何るる函

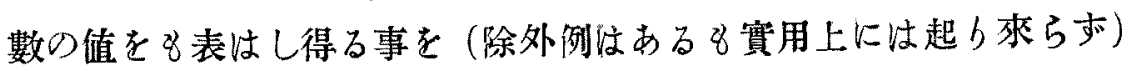
證明し得。(證明略方数學教科書竞見る可し)、上の如き次第现百故に 如何る万椱雑なる函數を8此如き級数(之を器級數上云ふ）にて表はし

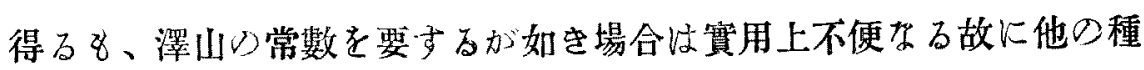

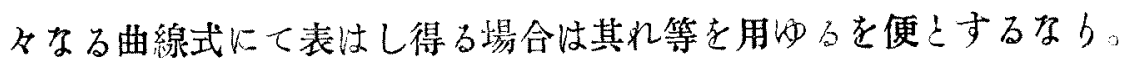
上の如き實驗公式は其當て嵌る範圊を明示すること絕對に必要なり。

$$
\begin{aligned}
& 80 \text {. 最小自珷法 } \\
& y=a+b x
\end{aligned}
$$

るる閣係すb觀测によりて

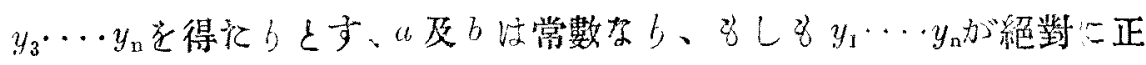
しき值㔔らば

$$
\begin{gathered}
a+b x_{1}-y_{1}=\mathrm{R}_{1} \\
a+b w_{2}-y_{2}=\mathrm{R}_{2} \\
a+b u_{3}-y_{3}=\mathrm{R}_{3} \\
\ldots \ldots \\
\ldots \ldots \\
\ldots \ldots \\
\ldots+b x_{\mathrm{n}}-y_{n}=\mathrm{R}_{n}
\end{gathered}
$$

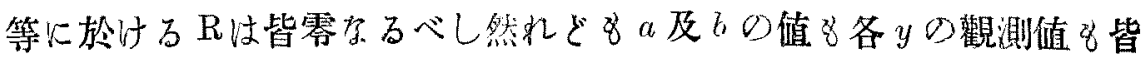


絕對に正しき能性ざるを以下上の $\mathrm{R}$ は一般に零とるらす、此場合に確 度算の理論上bして最8適當なる $a$ 及 $b$ の值法 $\Sigma \mathrm{R}^{2}=\mathrm{R}_{1}^{2}+\mathrm{R}_{2}^{2}+\mathrm{R}_{3}^{2} \cdots$ $\cdots \cdots \cdots+R_{\mathrm{n}}^{2}$ を最小にする $a$ 及 $b の$ 值なるてと孝證明し得（證明は 後に讓る)

$\mathrm{R}_{1}^{2}+\mathrm{R}_{2}^{2}+\cdots \cdots+\mathrm{R}_{\mathrm{u}}^{2}$ を最小るらしむる $a$ 及 $b$ 值を求むる算法怡次の 如し(理由性後に證明すべし) $a$ 及 $b$ を算出する方程式として

$$
\begin{gathered}
a+b x_{1}=y_{1} \\
a+b x_{2}=y_{2} \\
a+b x_{3}=y_{3} \\
\cdots \cdots \\
\cdots \cdots \\
\cdots \cdots \\
a+b x_{12}=y_{1}
\end{gathered}
$$

なる $n$ 個の方程式あり此の $n$ 個つ式上b只二個の根 $a$ 及 $b$ 求むる可 きが故に式の數が普通の方程式解法施行するものとしては多きに過 ぐ故に先づえれを本均すべし、總てり式を漫々相加へて

$$
\begin{aligned}
& a+b x_{1}=y_{1} \\
& a+b x_{2}=y_{2} \\
& a+b x_{3}=y_{3} \\
& \cdots \cdots \\
& \cdots \cdots \\
& \cdots \cdots \\
& a+b x_{\mathrm{n}}=y_{2}
\end{aligned}
$$

$$
n a+b\left(x_{1}+x_{2}+\cdots+x_{n}\right)=y_{1}+y_{2}+\cdots \cdots+y_{n}
$$


之を簡便の篇めに次の如く書く

$$
n a+b \Sigma x=\Sigma y \cdots \cdots \cdots \cdot(1)
$$

少一個の本均したる式を要す其の篇めには上の各式へ夫れ夫れ $x_{1}, x_{2}$ $\cdots x_{n}$ 老乘して加へ合す依少て

$$
\begin{aligned}
& a x_{1}+b x_{1}^{2}=y_{1} x_{1} \\
& a x_{2}+b x_{2}^{2}=y_{2} x_{2} \\
& \ldots \ldots \ldots . \\
& \frac{a x_{\mathrm{u}}+b x_{n}^{2}=y_{\mathrm{u}} x_{n}}{a \Sigma i+b \Sigma x^{2}=\Sigma c y \cdots \cdots}
\end{aligned}
$$

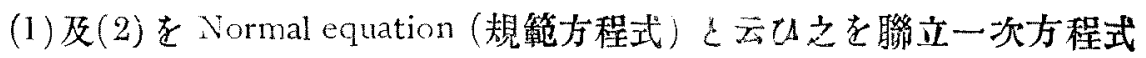
として $a$ 及它求む心゙し即ち

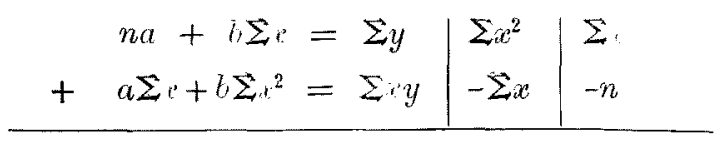

$$
\begin{aligned}
& a=\frac{\sum y \sum x^{2}-\sum x \sum x y}{n \sum x^{2}-\left(\sum x\right)^{2}} \\
& b=\frac{n \sum x y-\sum \sum \sum y}{n \sum x^{2}-(\Sigma x)^{2}}
\end{aligned}
$$

（普通最小自乘法に於ては $\Sigma x y \sum x^{2}$ 等と書く代bに[xy], [ $\left.x^{2}\right]$ 等と書く みb) 斯くして得たる $a$ 及 $b$ 精密度從つて $y=a+b x$ なる原式の正

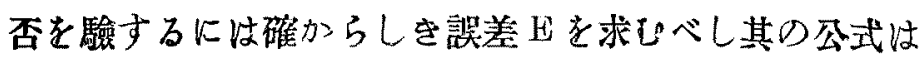

$$
\mathrm{E}=0,6745 \sqrt{\frac{\overline{\Sigma \mathrm{R}^{2}}}{n(n--1)}}
$$

§7. 變數がニつ以上ある時 
に8略同樣に計算するなら。

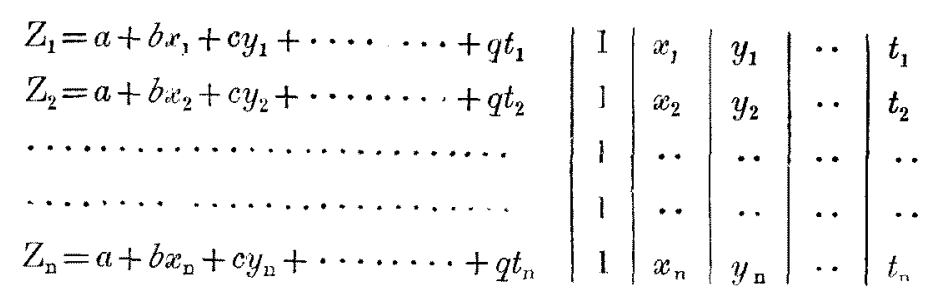

の方程式あb、但し $Z_{1}, Z_{2} \cdots Z_{n} \cdots n$ 個の實驗よb得たる数るb $x, y$

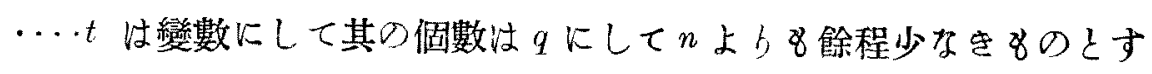

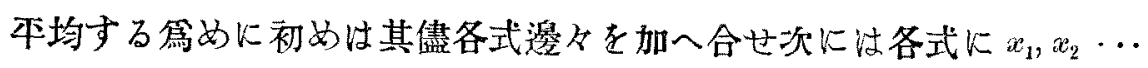

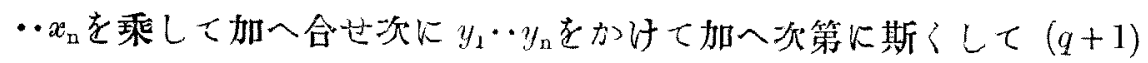
個の一次方程式を得心゙し之れ葆解さて $(q+1)$ 個の程 $a, b, c \cdots q$ を求し

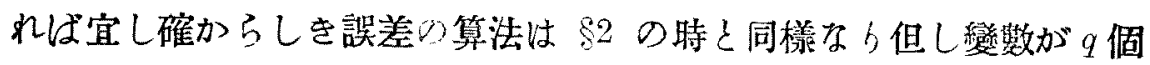
ある故に

$$
\mathrm{E}=0,6745 \sqrt{\frac{\bar{\Sigma} \mathrm{R}^{2}}{n(n-q)}}
$$

とるる $y=a+b t+c t^{2}$ の如さ㭙に戗上の場合に於七 $t$ を $x t^{2} を y$ と見 て計算すれば宜し。

\$8. 式の形の複雜みる場合

には時に應じて何等かの手段を用てAて常數の大略の值を求さべし例 ヘば

$$
y=\frac{a+b t}{(c+d t)^{4}}
$$

の如き場合下は理論上又は tryal 等に依りて大略の $a, b, c, d:$ 值を求 むべし真實の $a, b, c, d$, と大略の值 $a^{\prime}, b^{\prime}, c^{\prime}, d^{\prime}$ との差を $a-a^{\prime}=q_{1} b-b^{\prime}$ 


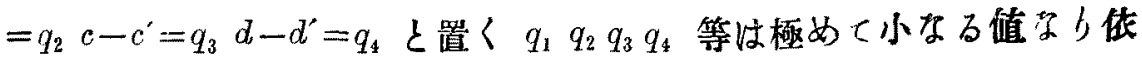
りて近似算法に從つて

$$
\begin{aligned}
y & =\frac{a^{\prime}+q_{1}+\left(b^{\prime}+q_{2}\right) t}{\left\{\left(c^{\prime}+q_{3}\right)+\left(d^{\prime}+q_{4}\right)\right\}^{4}}=\left\{a^{\prime}+q_{1}+\left(b^{\prime}+q_{2}\right) t\right\}\left\{c^{\prime}+d^{\prime} t+q_{3}+q_{4} t\right\}^{-4} \\
& =\frac{a^{\prime}+b^{\prime} t}{\left(c^{\prime}+d^{\prime} t\right)^{4}}\left(1+\frac{q_{3}+q_{4} t}{c^{\prime}+d^{\prime} t}\right)^{-4}\left(1+\frac{q_{1}+q_{2} t}{a^{\prime}+b^{\prime} t}\right) \\
& =\frac{a^{\prime}+b^{\prime} t}{\left(c^{\prime}+d^{\prime} t\right)^{4}}\left(1-4 \frac{q_{3}+q_{4} t}{c^{\prime}+d^{\prime} t}+\frac{q_{1}+q_{2} t}{a^{\prime}+b^{\prime} t}\right)
\end{aligned}
$$

師 $y=\mathrm{A}+\mathrm{B} q_{1}+\mathrm{C}_{q_{2}}+q_{3}+\mathrm{E} q_{4}$

但し

$$
\begin{aligned}
& \mathrm{A}=\frac{a^{\prime}+b^{\prime} t}{\left(c^{\prime}+d^{\prime} t\right)^{4}} \quad \mathrm{~B}=\frac{a^{\prime}+b^{\prime} t}{\left(c^{\prime}+d^{\prime} t\right)^{5}} \quad \mathrm{C}=\frac{t\left(a^{\prime}+b^{\prime} t\right)}{\left(c^{\prime}+d^{\prime} t\right)^{4}} \\
& \mathrm{D}=\frac{-4\left(a^{\prime}+b^{\prime} t\right)}{\left(c^{\prime}+d^{\prime} t\right)^{5}} \quad \mathrm{E}=\frac{-4 t\left(a^{\prime}+b^{\prime} t\right)}{\left(c^{\prime}+d^{\prime} t\right)^{5}}
\end{aligned}
$$

此れ等 $A, B, C, D, E の$ 五個の數壮 $t$ が與へらるれば計算し得る數み b、故に之れ没 870 場合の $x, y \cdots t$ と同心く見做して前と同樣に

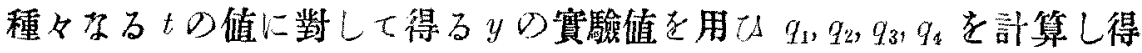

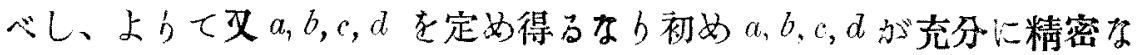

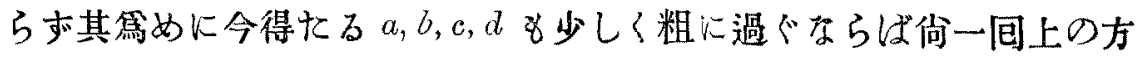
法を繰b返して少一層正しき $a . b, c, d$ D值在求凹べし、省上の例の外 に種々るる複雜なる函數の形あり之等は皆上と同樣汇展開して其の初 項老取る算法にて計算し得るるら。

89. 最小自乘の意味

$\$ 60$ 方法に一定文大る

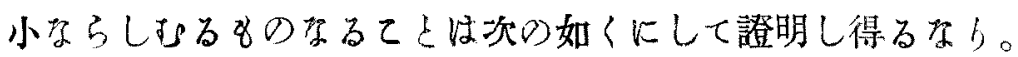




$$
\begin{aligned}
& R_{1}=a_{1}+b u_{1}-y_{1} \\
& \mathrm{R}_{\mathrm{z}}=a+b x_{2}-y_{2} \\
& R_{n}=a+b x_{n}-y_{n}
\end{aligned}
$$

るる故に $\Sigma \mathrm{R}^{2}=\mathrm{R}_{1}^{2}+\mathrm{R}_{1}^{2}+\cdots \cdots \cdot \mathrm{R}_{\mathrm{n}}^{2}=\left(a+b x_{1}-y_{1}\right)^{2}+\left(a+b x_{2}-y_{2}\right)^{2}+$ $\cdots \cdots \cdots+\left(a+b x_{n}-y_{n}\right)^{2}$

此の值を最小るらしむる $a$ 及 $b$ 值䝌大極小の定理によbて

$$
\frac{\partial \Sigma R^{2}}{\partial a}=0 \cdot \frac{\partial \Sigma R^{2}}{\partial b}=0
$$

ふる二つの聯立方程式の根として與へらる可し此の二式を明白に書

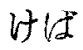

$$
\left.\begin{array}{l}
a+b x_{1}-y_{1}+a+b x_{2}-y_{2}+\cdots \cdots+\cdots+b+b x_{n}-y_{n}=0 \\
x_{1}\left(a+b x_{1}-y_{1}\right)+x_{2}\left(a+b x_{2}-y_{2}\right)+\cdots \cdots+x_{n}\left(a+b x_{n}-y_{n}\right)=0
\end{array}\right\}
$$

と㔔る、書き值して

$$
\left.\begin{array}{l}
n a+b \Sigma=\Sigma y \\
a \Sigma a+b \Sigma=\Sigma x y
\end{array}\right\}
$$

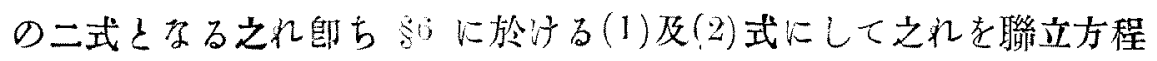

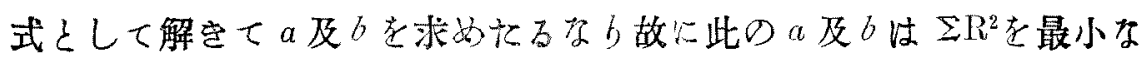
らしむる8の交。

\section{0. 重名 Weight 0 事}

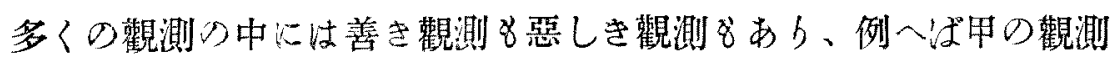

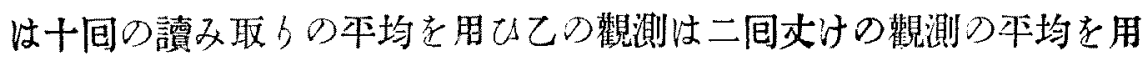


ひしとすれば甲の值が乙の值より8善を值るbと云ひ得心゙し、甲と乙 とを其の㦎本均し及は其の儘にて自乘法を行へば善き觀測の效力を無 益に減するてとにるる故に此の如さ場合は甲乙の觀測よb各一個つ方 程式を得るるらば甲の方程式は乙の8の五個丈けの價值ある8のと見

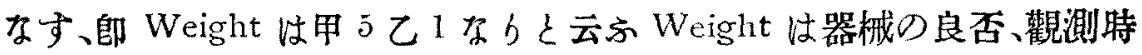

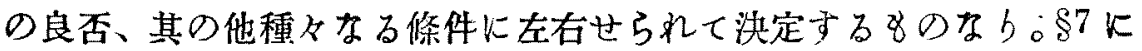
述べたる場合に於て第一の方程式の Weight は $\mathrm{P}_{1}$ 第二が $\mathrm{P}_{2}$ 第三が $\mathrm{P}_{3}$ 次 第を追てて最後の方程式のWeight が $\mathrm{P}_{n}$ 尔りをすべし然れば總て方 程式の雨邊に夫火 $\mathrm{P}_{1}, \mathrm{P}_{2}, \mathrm{P}_{3}, \cdots \mathrm{P}_{\mathrm{n}}$ 孛乘して得てる $n$ 個り式に就さて

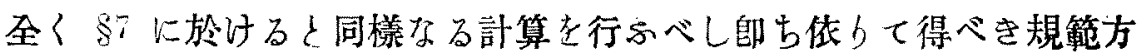
程方法

$$
\begin{aligned}
& {[\mathrm{P} z]=a[\mathrm{P}]+b[\mathrm{P} x]+c[\mathrm{P} y]+\cdots \cdots+q[\mathrm{P} t]} \\
& {[\mathrm{P} x z]=a[\mathrm{P} x]+b\left[\mathrm{P} x^{2}\right]+c[\mathrm{P} y x]+\cdots \cdot \cdots+\eta[\mathrm{P} t x]} \\
& \text { n........................... } \\
& {[\mathrm{P} t z]=a[\mathrm{P} t]+b[\mathrm{P} x t]+c\left[\mathrm{P} y t+\cdots \cdots+q\left[\mathrm{P} t^{2}\right]\right.}
\end{aligned}
$$

となる之れ老解さて $a, b, c, \cdots \cdots \cdots q$ を求されば宜し確からしき誤差 は

$$
\mathrm{E}=0,674.5 \sqrt{\frac{\sum \mathrm{PR}^{2}}{n(n-q)}}
$$

\$11. 誤差の理

$\$ 6$ に於て $y=a+b x$ の常數 $a$ 及 $b$ の最8適當るる值は $\Sigma \mathrm{R}^{2}$ を最小 
ならしひるすかなることを述べたら、此意味を說明する第には先づ誤 差の理を了解するを要す、誤差とは觀測值と具賽の值との差にして種

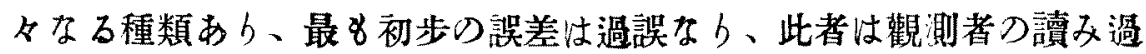
り等上り起る8のなb、充分に泩意すれば免る 在得可し。次のは系 統誤差 Systematic error Kして、之れ忟器差、實驗法の不完全等に基づ く8のるら、實驗の結果と計算の結果と比較して誤差が總て正るりと

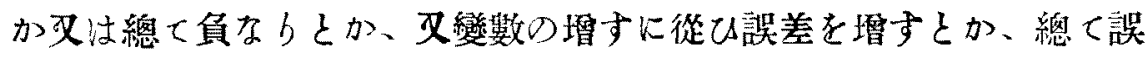
差つ間に或一種つ規則的變化加認め弓る、時に注必何等加系統的㛊差 のある證據なら、故に原因を考求して補正せざる可ら方。過誤8 なく 又系統的誤差8除さて8少一種の誤差殘る、之を偶然誤差 Accidental error と名く、例へば $0.1^{\circ} \mathrm{C}$ が一粍に刻みある寒暖計を用て 分り一度の枌迄目分量を用して溫度を計るとす可し、計らんとする溫 度が全く一定の8のとする8非常に熟練したる觀測者子らすんば百分 の一度の枌にては讀み取りに多少の差起る可し、8し8多少の氣流等

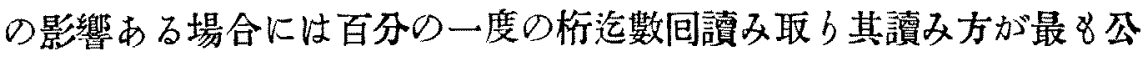
本なる讀み方子りとして8少最後の枌䬣 $0.1^{\circ} \mathrm{C}$ の處に於ては讀み取 b毎に數字に多少の相違起る可し、此如さ誤差性偶然子る原因に因b て起る8のにして如何なる熟練したる觀測者8避け難さ處なb、此誤 差や其原因全く偶然るる故に其個々の㗊差が如何に起るかに就さては 全く何人8知難く又何等の理由を見出し難く從て不規則極まる8の るら、然れど落に無数に多き觀測ある時には之等の際に起る誤差の 間に自づから一の法則が生ずるるら、此事は實に統計學の原理とする 
處にして又宇宙間萬般の現象を支配して大威力ある名のる h、今此方 則を簡單子る例に由bて次化説明す可し。

\section{2. 偶然誤差及洗則}

今射的をな寸8のあり、常に正中せしめん之欲声れども正中する場

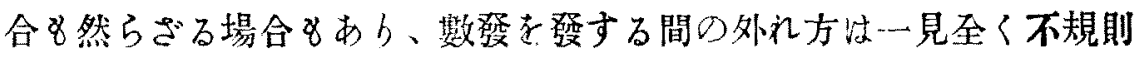
なるが如さ8熟練かる射手に数干發を發せしめて後之れを检するに全

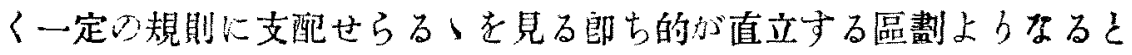
し正中線の雨側に等區劃線苍引き其畫線間に落ちでる强九數を計算す

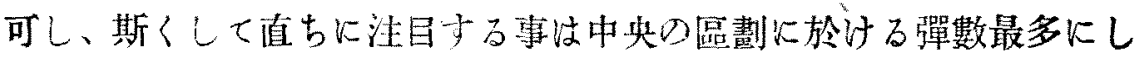

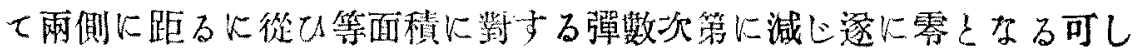
其状況は下圖心如し。

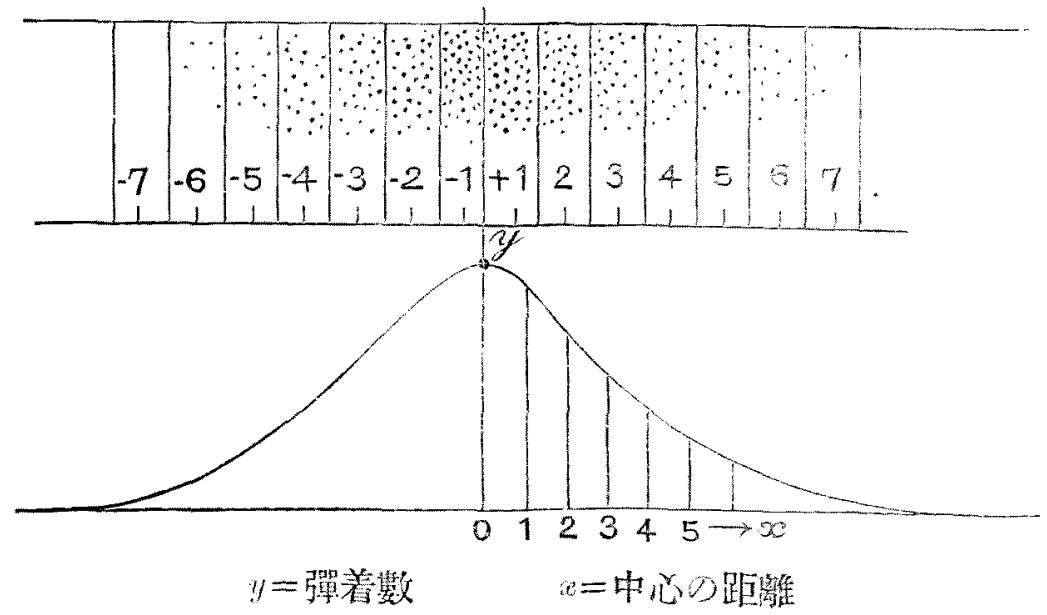

圖の上部憚着寺す8の、下部は彈着數を曲線にて示したる8のみ b、等面積內の彈着數牥中央が最大に左右に去るに從し減亦る者子b 


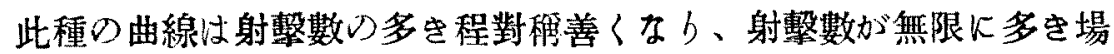
合以は所謂確度曲線 Probability curve となる、其式は

$$
y=\frac{h}{\sqrt{\pi}} \mathrm{e}^{-h^{2} e^{2}}
$$

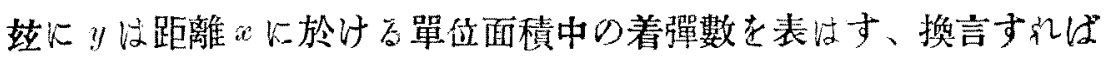

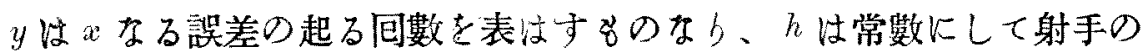
上手下手に關す、即一般實驗上には實驗法の功拙、器械の精粗等に關

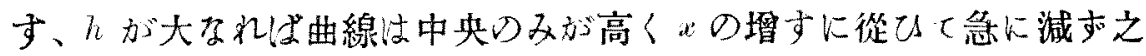

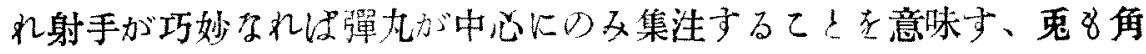
此曲線上るして明るるてとは小尔誤差の起る间数郎確度は大るる誤

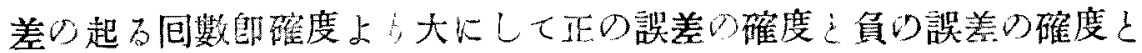

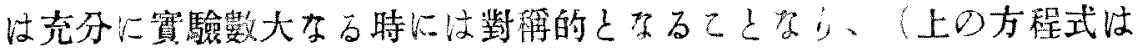

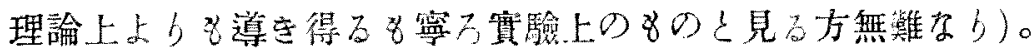

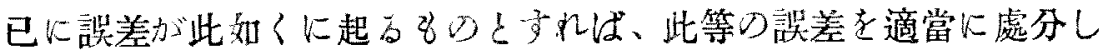

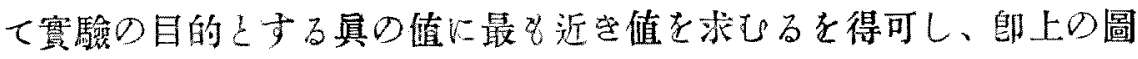

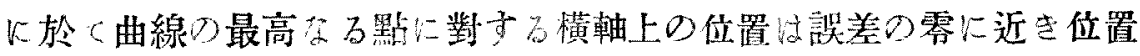
なるてとを示す、計算に依らて此位置を求しるには總てり觀測値の平

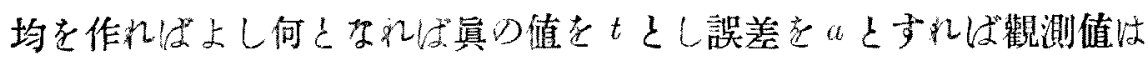

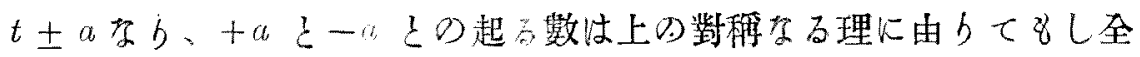
回數が無限に多を場合に怯相等し、故に或る十aに對して必或－aが ある可を故に全體り本均を取れば+とーに消し合で $t$ 文が殘る可し

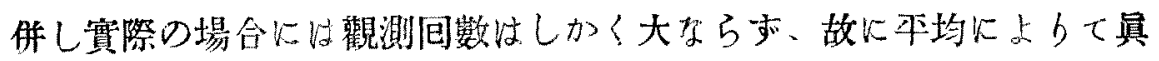


36

の值 $t$ を得ホして最8確らしさ值を得るなら郎

$$
m=\frac{\Sigma(t+a)}{n}=\frac{\Sigma v}{n}
$$

丝に $v$ は觀測值 $n$ 壮觀測问數なら。

$\$ 13$. 確からしき誤差

次に $m$ は $t$ 近さを之れに等しからす、其れと幾何の差あるかは素 よb何人8知b難き處なる8聯に確からしき誤差 (probable error)なる 80を考ふる索得可し、素上b便宜上の8のなる8之を以て誤差の程 度を決定し得可し、上の射的の曲線圖に於て、上手てる射手に對する 曲線は高く細くるり、下手学る射手に對する分は本たく厚くなると云 へら郎ち下圖の如し、故に射擊の上手下゙手郎誤差の大小の程度を定む

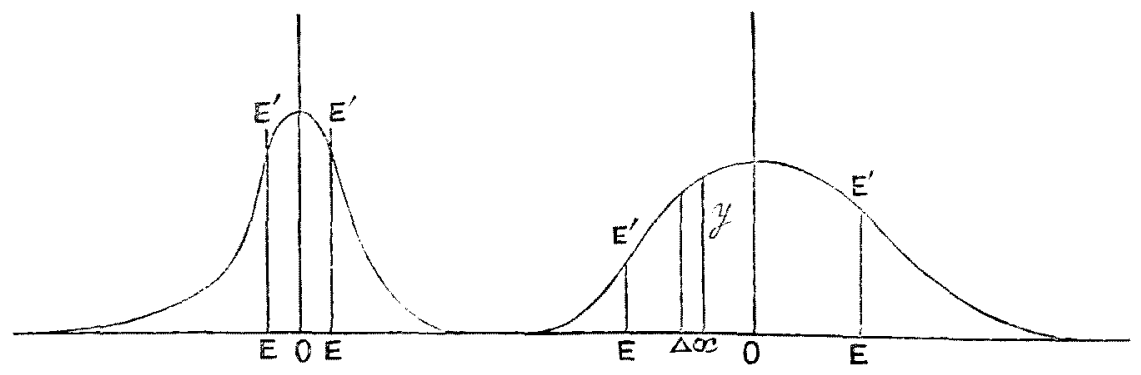

る壆に此曲線と横軸との間の面積を利用し得可し、今中心線の左右等 距離に於て二線 $\mathrm{E} \mathrm{E}$ を学き此線より外側の面積と內側の面積とが相 等しき棣に取る可し、誤差がOより $\mathrm{E}$ 迄の間に在る確度(包數)は $\mathrm{O}$ $\mathrm{E}$ との間の面積に比例し又誤差が Eよb8少大子万可さ磪度は Eよb 8 外側に在る面積に比例す可し、(何とるれは圖に於て $y$ は国僌走示す 故に $x$ の小片 $\triangle x$ に對する回數恃正にy $\Delta x$ にして $\triangle x$ の上に立つ面積 


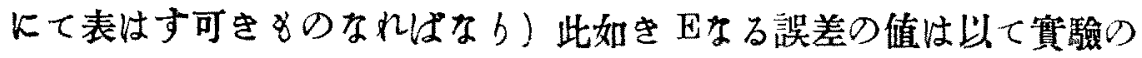
精粗を定むるに足る可し、Eが大るれば賽驗泣粗るら、Eが小るる程

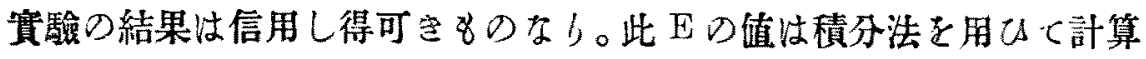
寸る在得(計算略)其傎法

$$
\mathrm{E}=\cdot 0.6745 \sqrt{\frac{\sum(v-m)^{2}}{n(n-1)}}
$$

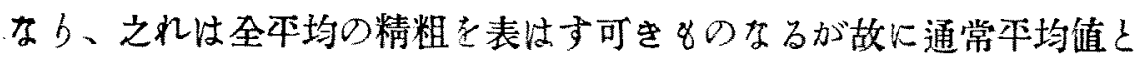
して $m \pm \mathrm{E}$ を以て答とす、鄐單に

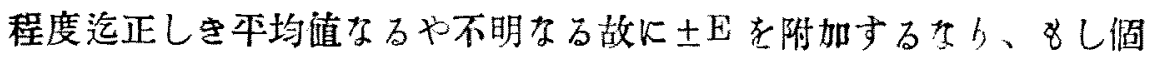
タの觀測值 $v$ の確からしき諮差 $e$ を要するならば

$$
e=0.6745 \sqrt{\frac{\sum(v-m)^{2}}{n}}
$$

なる公式を用め可し。

其他變數の多き場合、重みのある場合等は已に夫れ夫江の場合に示

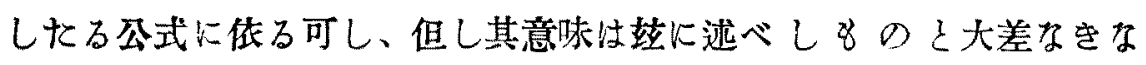
b.

§14. こR²を最少ならししることの意味

86 に於ては $\Sigma \mathrm{R}^{2}$ を最小るらしひる りと述心゙扢々一其の理由を說明すべし常識上り考へて8 實測と觀測值 との差大るRの自乘の和が最小になる常數ひ值は餘程確からしき值な るてとを考へ得心゙，㒂て觀測が充分に澤山なれば偶然誤差の配布は規

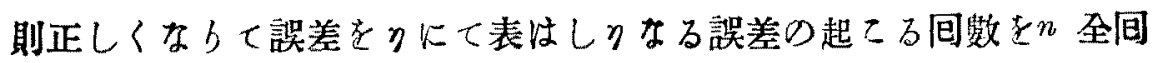


數をNにて表はせばクの起てる確度Pは\$12の公式によbて

$$
\mathrm{P}=\frac{n}{N}=\frac{h}{\sqrt{\pi}} e^{-h^{2} \eta^{2}}
$$

今 86 D場合に返bて

$$
\begin{aligned}
& a+b x_{1}-y_{1}=\eta_{1} \\
& a+b x_{2}-y_{2}=\eta_{2} \\
& \ldots \ldots \ldots \ldots \\
& \cdots \ldots \ldots \\
& a+b e_{n}-y_{\mathrm{n}}=\eta_{\mathrm{n}}
\end{aligned}
$$

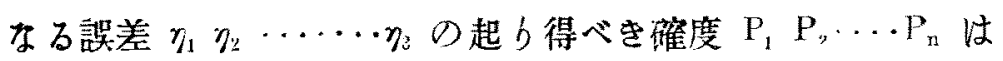

$$
\begin{aligned}
& \mathrm{P}_{1}=\frac{h}{\sqrt{\pi}} e^{-h^{2} \eta_{1}^{2}} \\
& \mathrm{P}_{2}=\frac{h}{\sqrt{\pi}} e^{-h^{2} \eta_{2}^{2}} \\
& \mathrm{P}_{n}=\frac{h}{\sqrt{\pi}} e^{--h^{2} \eta_{\mathrm{b}}^{2}}
\end{aligned}
$$

此等の誤差の同特に起てる確度 P性度算の定理に由bて各の確度 の積とるる郎

$$
\mathrm{P}=\mathrm{P}_{1} \mathrm{P}_{2} \mathrm{P}_{3} \cdots \mathrm{P}_{\mathrm{n}}=\left(\frac{h}{\sqrt{\pi}}\right)^{\mathrm{u}} e^{-h_{2}\left(\eta_{1}^{2}+\eta_{2}^{2}+\cdots \cdots+\eta_{\mathrm{n}}^{2}\right)}
$$

偖探用したる $a$ 及 $b$ が最8正しき場合には此の確度 Pは最大るる可 し、 $a$ 及 $b$ が正しき值を去るに從て確からしさ減少可さ故にP性次第に

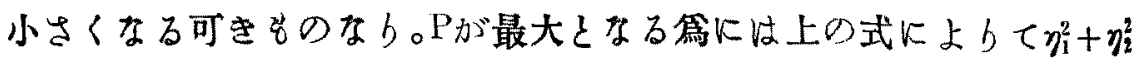
$+\cdots \cdots+\eta_{\mathrm{n}}^{2}$ が最小となるを要す。 
此の $\eta_{1} \eta_{2} \cdots \eta_{n}$ 性先に殘餘の意味を有せしめて $\mathrm{R}_{1}, \mathrm{R}_{2} \cdots \cdots \mathrm{R}_{\mathrm{n}}$ と書

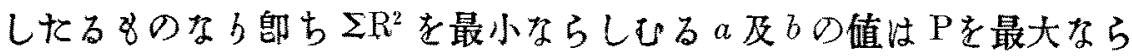
しむる䬦ち換言すれば最8確からしき值なり。 